\title{
Recap of Media Democracy Days 2015: Taking on the Federal Election
}

\author{
Christine Ackerley
}

School of Communication

Simon Fraser University

\section{Sydney Ball}

Media Democracy Project

Simon Fraser University

Over the 15 years since its inception Media Democracy Days (MDD) has provided a chance for the public to gather with members of Canadian independent media, journalists, and activists to discuss alternative media and the future of Canadian journalism. This year the MDD community came together with the goal of sharing what has been learned about alternative media practices in light of the recent federal election. MDD took place on November 7th at the Vancouver Public Library and was held in partnership with the SFU School of Communication, OpenMedia, Vancouver Public Library, and Fonds Graham Spry Fund.

Jesse Brown from CANADALAND delivered the Spry Memorial Lecture to a packed room of more than 300 people. Brown is best known for his investigative reporting on sexual abuse and harassment allegations against former CBC host Jian Ghomeshi. CANADALAND is crowd-funded news site and podcast network dedicated to media criticism.

Brown's work focuses on the ethos that journalism should be serving the public good, and CANADALAND, as a result, often reports on stories about what obstructs journalists from breaking stories and doing the work they feel is important. His keynote was titled "Things You Shouldn't Say in Canada," and it tied together stories of journalists working in Canada who faced negative consequences for their reporting. Brown argued that journalists' fears of being sued for defamation - sometimes called the "libel chill" - only partially explain the timidity of Canadian newsrooms. Since a Supreme Court ruling in 2009, the "responsible communication" defence has granted journalists reporting on issues of public importance the right to be wrong in certain circumstances. Instead, problems around insufficient libel protection for freelance journalists, commercial funding structures, and personal career risks provide the major disincentives for journalists to do work that challenges power. He further pointed out that journalists face huge risks when they publish controversial stories: they may lose their jobs, face huge financial consequences, and hurt their reputations. However, some journalists - committed to reporting in the public interest - still take those risks. Unfortunately, Brown said that most of this reporting is being pushed out of newsrooms, and onto the shoulders of freelancers and alternative media organizations.

Brown has been closely following the case of Laura Robinson, who wrote a story in the Georgia Straight about sexual and physical abuse allegations against former Vancouver Olympics CEO John Furlong. Furlong sued Robinson for defamation, and even though the claim was eventually dropped, Robinson was not covered under the Georgia Straight's libel protection and the litigation cost her an incredible amount of money and has hurt her career as a journalist, said Brown. Robinson later opened a libel case against Furlong and lost.

Likewise, Brown recounted the story of journalist Paul Watson, who chose to resign from the Toronto Star because he was told by his editor to drop a story exposing inaccurate coverage of the expedition that found the Franklin shipwreck in the Canadian Arctic. Brown noted that there are several theories to why the Toronto Star wanted Watson to keep quiet, but ultimately it meant that a journalist was discouraged to report in the public interest.

Both cases have been extensively covered by Brown on CANADALAND, and the lecture drew from these and other notable stories Brown has been covering over the last several years to make a case 
that the funding structures of mainstream newsrooms are hindering investigative journalism in Canada. Due to corporate media concentration in Canada and the lack of government support for public broadcasters this issue is being exacerbated over time. CANADALAND's crowdsourcing model means that they get paid to break stories, not paid by advertisers for producing the most clicks or views, said Brown. This motivates CANADALAND to satisfy a smaller audience looking for hard-hitting investigations, rather than seeking to attract the broadest audience possible.

After the keynote, the first panel, "Stop Spying on Us" addressed the technical, legal, and political challenges Canadians face in working to protect and defend their privacy online. Panelists were Steve Anderson, the founder and Executive Director of OpenMedia; Micheal Vonn, the Policy Director of the BC Civil Liberties Association; Andrew Clement, a Professor Emeritus in the Faculty of Information at the University of Toronto; and was moderated by Adel Iskandar, an assistant professor of Global Communication at Simon Fraser University. The panelists discussed the implications of Bill C51 , and other privacy concerns to focus on post-election. This discussion remains timely as many people's reservations about the newly elected government stem from their inadequate or ambiguous addressing of privacy concerns, and as Steve Anderson said during the panel, "a privacy deficit equals a democracy deficit."

The second panel "Beyond Fear \& Great Hair: Shaping Debate in \#Elxn42" brought together groups who were active in the campaign to share their experiences, reflect on their strategies, and offer some thoughts about citizen engagement in the post-election landscape. Panelists were Donald Gutstein, author of "Harperism"; Jamie Biggar, the campaigns director for Leadnow; Anastasia Gaisenok, the Executive Director of Check Your Head; and Tara Mahoney, the Co-Founder and Creative Director for Gen Why Media. The panel was moderated by Milan Singh, who recently completed her $\mathrm{Ph}$.D. in the School of Communication. It was fantastic to have these voices connect after their respective organizations, including Up For Debate, Lead Now, and Creative Publics, were so active in the weeks leading up to election. Donald Gutstein provided an energetic closing to the panel on why "corporate media should not be the gatekeepers of the public mind" and why the work of these individuals remains essential to activism and politics.

The third and final panel, "Changing the Channel: News, Independent Media and Campaign 2015," discussed the role of investigative journalism and critical political analysis in informing citizens, empowering marginalized voices, and exploring the relationship between politics and the public good. The panelists were Leena Minifie, the Editor of the Indigenous Reporting Fund at Ricochet Media; Michael Stewart, the Blogs Editor at rabble.ca; Jim Mainguy, with The Redeye Collective on Vancouver Co-op Radio; and Jenny Uechi, managing director of the Observer Media Group. The panel was moderated by Anis Rahman, a Ph.D. Candidate in the School of Communication at Simon Fraser University. These individuals all work in independent news organizations and have has to overcome the challenges of providing investigative reporting. They provide content that is often ignored by mainstream sources, and, as Jenny Uechi noted during the panel, a healthy media system is a "more diverse one." To hear of their unique struggles, such as finding an audience or doing diligent accurate work by report from within Indigenous communities, provided context to the task of creating journalism that serves Canadians.

Throughout the day, more than 20 organizations working in alternative media participated in MDD's Media Fair. Participants included Amnesty International, BC Civil Liberties Association, Check Your Head, City Hall Watch, CJSF, Vancouver Co-op Radio, Hello Cool World, Love Intersections, the Mainlander, Metro Vancouver Watch, OpenMedia, Our City of Colours, The Peak, rabble.ca, Ricochet, The Source, Theatre for Living, Vancouver Indigenous Media Arts Festival, W2 Media, Women, Action, \& the Media, and World Media in English. These groups set up table displays and interacted with people walking through the upstairs promenade of the library. 
The first MDD was held in 2001, organized by local Toronto and Vancouver members of the Campaign for Press and Broadcast Freedom. Since 2010, MDD has been led by the School of Communication at SFU, OpenMedia, and the Vancouver Public Library, and aims to create a significant presence for non-commercial media in Canada. 